\title{
MEĐUNARODNA TRGOVINA ZEMALJA ČLANICA OPEC-a
}

\author{
Petar Mišević 23
}

UDK / UDC: 339.5:061(100)

JEL klasifikacija / JEL classification: F1, F13

DOI: https://doi.org/10.22598/pi-be/2019.13.2.223

Pregledni znanstveni rad / Scientific review

Primljeno / Received: 29. kolovoza 2019. / August 29, 2019

Prihvaćeno za tisak / Accepted for publishing: 21. listopada 2019. / October 21, 2019

\section{Sažetak:}

Organizacija zemalja izvoznica nafte (OPEC) kao međunarodna organizacija svojim instrumentima korekcije cijena naftnih derivata značajno utječe na gospodarske sustave $i$ međunarodnu trgovinu diljem svijeta. Rad analizira međunarodnu trgovinu zemalja članica OPEC-a za razdoblje od 2013. do 2017. godine. U analizi korišteni su pokazatelji trgovinske ravnoteže, intraindustrijske razmjene, udjela izvoza u uvozu, trgovinske otvorenosti $i$ udjela izvoza u BDP-u. Rezultati istraživanja pokazat će koliko su trgovinski otvorene te izvozno orijentirane zemlje članice OPEC-a. Na temelju rezultata istraživanja prezentiraju se preporuke i prijedlozi istraživanja.

Ključne riječi: pokazatelji vanjskotrgovinske razmjene, OPEC, izvoz, uvoz.

\section{UVODNA RAZMATRANJA}

OPEC, kao Organizacija zemalja izvoznica nafte predstavlja međuvladinu organizaciju od 14 zemalja. Osnovana je 1960. godine u Bagdadu od strane prvih pet članica, a to su Iran, Irak, Kuvajt, Saudijska Arabija i Venezuela. Razvili su kolektivnu misiju, postavili ciljeve i osnovali prvo sjedište u Ženevi, koje se 1965. preselilo u Beč.

23 Doc.dr.sc. Petar Mišević, docent, Sveučilište Sjever, Varaždin, E-mail: pmisevic@unin.hr 
Zemlje članice OPEC-a usvojile su tzv. Deklaratornu izjavu o naftnoj politici u državama članicama koja predstavlja neotuđivo pravo svih zemalja na njihove prirodne resurse u interesu njihovog nacionalnog razvoja. Misija OPEC-a je koordinirati i ujediniti politike svojih država članica i osigurati stabilizaciju tržišta nafte kako bi se osigurala učinkovita, ekonomična i redovita opskrba potrošača naftom, stalni prihod proizvođačima i fer prinos na kapital za one koji ulažu u naftnu industriju (OPEC, 2019).

U 2019. godini međunarodnu organizaciju OPEC čini 14 zemalja izvoznica nafte među kojima su Alžir, Angola, Ekvador, Ekvatorska Gvineja, Gabon, Indonezija, Irak, Iran, Kuvajt, Libija, Nigerija, Saudijska Arabija, Ujedinjeni Arapski Emirati i Venezuela (CFR, 2019). Ono što je organizaciju OPEC karakterizira jest utjecaj na cijene nafte čiji se utjecaj prelijeva na gospodarski razvoj velikog broja zemalja svijeta. Prema CFR-u (2019), takva dominantna tržišna pozicija ponekad je OPEC-u omogućila da djeluje kao kartel, usklađujući razine proizvodnje među članovima kako bi manipulirala globalnim cijenama nafte. Griffin (1985) zaključuje da većina zemalja OPEC-a funkcioniraju kao kartel, dokazi o sposobnosti OPEC-a o utjecaju na cijenu nafte je različit. Radovi iz 1980ih i 1990-ih implicirali su na tajnih dogovora. (Almoguera et al., 2011), ali kasnije studije (Spilimbergo, 2001; Smith (2005; Boug et al., 2016), pronašli su mješovite dokaze o tome je li je OPEC funkcionirao kao kartel.

Kroz svoje postojanje OPEC se kontinuirano suočavao s različitim situacijama i izazovima. Turbulentni odnosi s SAD-om, podjela između zemalja članica samo su neka od ograničenja stabilnog funkcioniranja OPEC organizacije. Primjera radi, u siječnju 2019., godine Katar se službeno povukao iz OPEC-a, signalizirajući svoje neodobravanje zbog dominacijom Saudijske Arabije nad organizacijom i trenutnom blokadom zemlje od strane Saudijske Arabije. OPEC provodi i politiku suradnje s Rusijom i nekoliko drugih glavnih izvoznika nafte poput koordinacije proizvodnje i izrade zajedničke povelje. Kruna suradnje je formalizacija nove koalicije OPEC + u srpnju 2019. godine, unatoč prigovorima SAD-a.

Nužno je istaknuti kako neke od zemalja OPEC-a nastoje diversificirati rizik pada cijene nafte te pritom postati manje ovisni o prihodima od prodaje nafte kroz ulaganja u razvoj tercijarnog sektora (npr. turizam, transport u Ujedinjenim Arapskim Emiratima).

U istraživanju je poseban naglasak stavljen na otvorenost vanjskotrgovinske razmjene 14 zemalja članica međunarodne organizacije OPEC. Korištenjem pokazatelja vanjske trgovine analizirat će se vanjskotrgovinska razmjena, otvorenost svake od zemalja ali i prosječna vrijednost svih zemalja članica OPEC-a. u razdoblju od 2013. do 2017. godine. Temeljna hipoteza rada pretpostavlja visoku trgovinsku otvorenost i izvoznu orijentiranost većine zemalja članica OPEC-a. 


\section{METODOLOŠKI OKVIRI}

Analiza se temelji na rezultatima relevantnih pokazatelja vanjskotrgovinske razmjene. Podaci su preuzeti iz statističke baze WDI (2019). Podaci služe u izračunavanju pokazatelja intraindustrijske razmjene, trgovinske ravnoteže, omjera izvoza i uvoza, trgovinske otvorenosti i udjela izvoza u BDP-u 14 zemalja OPEC-a i OPEC. Referentno razdoblje istraživanja je od 2013. do 2017. godine. U nastavku svaki od korištenih pokazatelja je zasebno metodološki obrađen. Pokazatelji su korišteni, između ostalog, iz recentnih istraživanja poput Kandžija et.al, (2014), Bezić i Galović (2014), Galović et al. (2017), Galović et.al. (2018).

Određena istraživanja čimbenika koji utječu na uspjeh ili neuspjeh napora u promicanju industrijalizacije, rasta zaključuju da rastuća razina intraindustrijske razmjene ima važan pozitivan značaj (Svjetska banka, 2018). Intraindustrijska razmjena donosi dodatne dobitke od međunarodne trgovine čak iznad onih koji su povezani s komparativnim prednostima. Time omogućuje zemlji iskorištavanje prednosti većih tržišta. Intraindustrijska razmjena (IITR) predstavlja vrijednost ukupne trgovine koja ostaje nakon oduzimanja apsolutne vrijednosti neto izvoza ili uvoza određene zemlje. U funkciji usporedbe između zemalja i industrija, mjere su izražene kao postotak izvoza i uvoza svake industrije. Vrijednosti indeksa variraju između 0 i 100. Što su vrijednosti bliže 100, proizvodi koji se uvoze i izvoze više dolaze iz iste industrije. Ako zemlja izvozi i uvozi približno jednake količine određenog proizvoda, vrijednost indeksa je visoka. Ako je trgovina uglavnom jednosmjerna (izvoz ili uvoz), vrijednost indeksa je niska. Jednadžba za navedeni indikator je prikazana u nastavku:

$$
\mathrm{IITR}_{i}=1-\left(1-\frac{\mid \operatorname{expo}_{i}-\text { impo }_{i} \mid}{\text { expo }_{i}+\text { impo }_{i}}\right) \times 100
$$

gdje je:

expo $_{i}-$ izvozna aktivnost države " $i$ "

impo $_{i}$ - uvozna aktivnost države " $i$ "

Sljedeći pokazatelj koji se koristi u istraživanju je pokazatelj trgovinske ravnoteže (TBAL). Izračunava se kao razlika između vrijednosti uvoza, izvoza dobara i usluga. Izračun se temelji na realnim vrijednostima nacionalnih valuta Pokazatelj trgovinske ravnoteže koristi se u makroekonomskim istraživanjima kojima se mjeri sektorska konkurentnost ili konkurentnost gospodarstva. Kada uvoz dobara i usluga nadmaši izvoz, onda se govori o trgovinskom deficitu. Ako je situacija suprotna, onda je indikativan trgovinski suficit. TBAL se izračunava temeljem sljedeće jednadžbe: 


$$
\mathrm{TBAL}_{i}=\operatorname{expo}_{i}-\operatorname{impo}_{i}
$$

gdje je:

expo $_{i}$ - izvozna aktivnost države " $i$ "

impo $_{i}$ - izvozna aktivnost države " $i$ "

Udio izvoza u uvozu (EXIM) predstavlja omjer izvoza i uvoza čiji je rezultat izražen u postotcima. EXIM pokazatelj je izražen sljedećom jednadžbom:

$$
\operatorname{EXIM}_{i}=\frac{\operatorname{expo}_{i}}{\operatorname{impo}_{i}} \times 100
$$

gdje je:

expo $_{i}$ - izvozna aktivnost države " $i$ "

impo $_{i}$ - izvozna aktivnost države "i"

Stupanj otvorenosti mjeri otvorenost ekonomije. Izračunava se kao zbroj vrijednosti ostvarenog izvoza i uvoza u odnosu na ostvareni bruto domaći proizvod u određenom razdoblju.

$$
\mathrm{TOI}_{i}=\frac{\operatorname{expo}_{i}+\text { impo }_{i}}{G D P}
$$

gdje:

expo $_{i}$ - izvozna aktivnost države " $i$ "

impo $_{i}$ - uvozna aktivnost države " $i$ "

$G D P$ - bruto domaći proizvod promatrane države

Povećanjem zbroja izvoza i uvoza u okviru bruto domaćeg proizvoda promatranog razdoblja rezultira većim stupnjem otvorenosti ekonomije te implicira veću uključenost međunarodne vanjskotrgovinske tokove. Pokazatelji koji mjere stupanj otvorenosti država jasno predočavaju stabilnost i uključenost vanjskotrgovinskog sektora u vanjskotrgovinske tokove.

Kada se mjeri izvozna propulzivnost uzimaju se u obzir sljedeći elementi:

$$
\mathrm{EGDP}_{i}=\frac{\text { expo }}{G D P}
$$


gdje je:

expo - izvozna aktivnost države " $i$ "

$G D P$ - bruto domaći proizvod promatrane države

Rast udjela robnog izvoza u okviru bruto domaćeg proizvoda u određenom razdoblju indicira na veću propulzivnost izvoza ekonomije. Suprotno tome, smanjenje udjela robnog izvoza u BDP-u ekonomije naglašava manju izvoznu propulzivnost.

\section{REZULTATI ISTRAŽIVANJA}

U ovom dijelu istraživanja prikazani su rezultati pokazatelja intraindustrijske razmjene, trgovinske ravnoteže, omjera izvoza i uvoza, trgovinske otvorenosti i udjela izvoza u BDP-u. Istraživanje analizira 14 zemalja članica OPEC-a i OPEC od 2013. do 2017. godine. U nastavku su prikazani rezultati pokazatelja intraindustrijske razmjene za zemlje OPEC-a i za OPEC u promatranom razdoblju (Tablica 1. i Grafikon 1.)

Tablica 1. Pokazatelj intraindustrijske razmjene (IITR) za zemlje OPEC-a od 2013. do 2017. godine

\begin{tabular}{|l|r|r|r|r|r|}
\hline Zemlja/Godina & $\mathbf{2 0 1 3}$ & $\mathbf{2 0 1 4}$ & $\mathbf{2 0 1 5}$ & $\mathbf{2 0 1 6}$ & $\mathbf{2 0 1 7}$ \\
\hline Iran & 69 & 73 & 80 & 68 & 66 \\
\hline Irak & 81 & 61 & 92 & 90 & 84 \\
\hline Kuvajt & 41 & 47 & 73 & 80 & 76 \\
\hline Saudijska Arabija & 61 & 66 & 90 & 84 & 73 \\
\hline Venezuela & 68 & 71 & 86 & 69 & 50 \\
\hline Libija & 77 & 95 & 95 & 98 & 65 \\
\hline Ujedinjeni Arapski Emirati & 87 & 88 & 93 & 95 & 93 \\
\hline Alžir & 91 & 99 & 80 & 78 & 87 \\
\hline Nigerija & 66 & 62 & 82 & 97 & 83 \\
\hline Ekvador & 96 & 97 & 92 & 98 & 98 \\
\hline Angola & 57 & 66 & 67 & 55 & 49 \\
\hline Gabon & 53 & 57 & 71 & 66 & 59 \\
\hline Ekvatorijalna Gvineja & 36 & 34 & 40 & 39 & 28 \\
\hline Kongo & 89 & 68 & 69 & 73 & 72 \\
\hline OPEC & 69 & 70 & 79 & 78 & 70 \\
\hline
\end{tabular}

Izvor: Izrada autora prema bazi statističkih podatka WDI (2019) 
Grafikon 1. Pokazatelj intraindustrijske razmjene (IITR) za OPEC od 2013. do 2017. godine

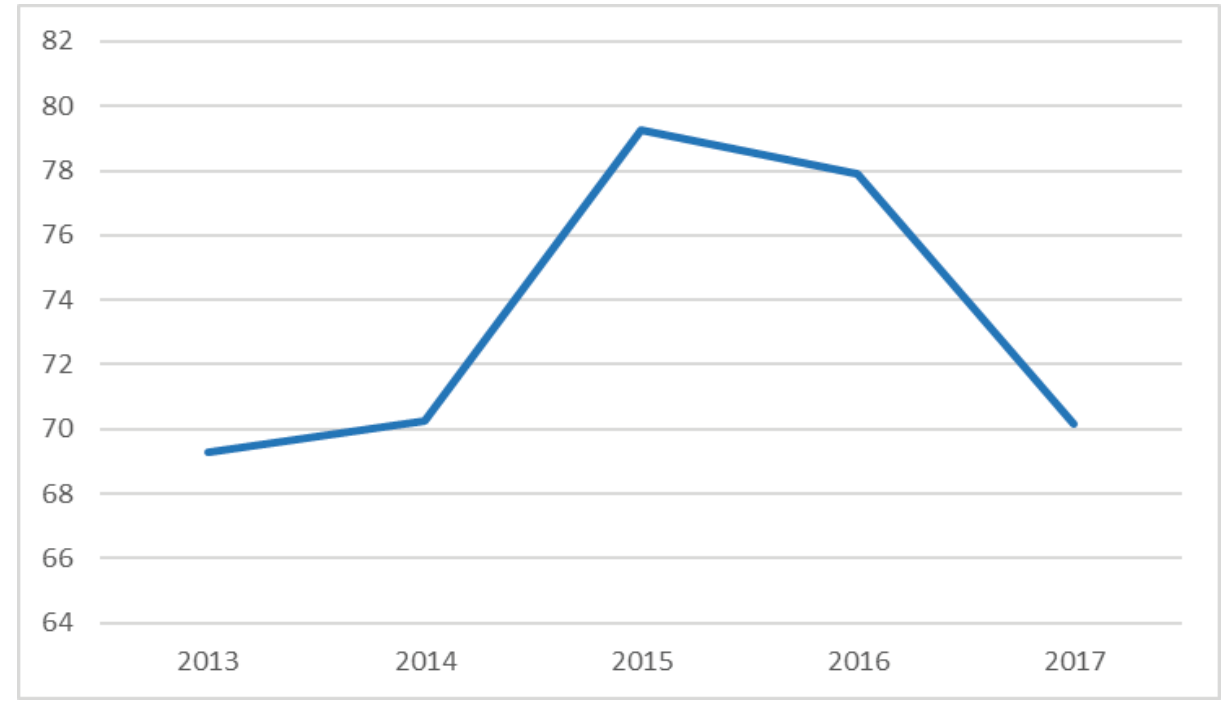

Izvor: Izrada autora prema bazi statističkih podatka WDI (2019)

Iz priloženog može se zaključiti kako vrijednost pokazatelja intraindustrijske razmjene za OPEC ima volatilno kretanje. Drugim riječima, od 2013. do 2015. godine zabilježen je rast IITR pokazatelja dok 2015. do 2017. godine IITR pokazatelj obilježava silazni trend. Zemlje OPEC-a koje nisu trgovinski jednosmjerne su Ekvador te Ujedinjeni Arapski Emirati. Vidljivo je kako je Ekvador proširio svoj trgovinski portfelj, zajedno s Ujedinjenim Arapskim Emiratima. Ujedinjeni Arapski Emirati su se etablirali kao poznata turistička destinacija što ukazuje na usmjerenost prema tercijarnom sektoru. 
Grafikon 2. Pokazatelj vanjskotrgovinske ravnoteže (TBAL) za OPEC od 2013. do 2017. godine

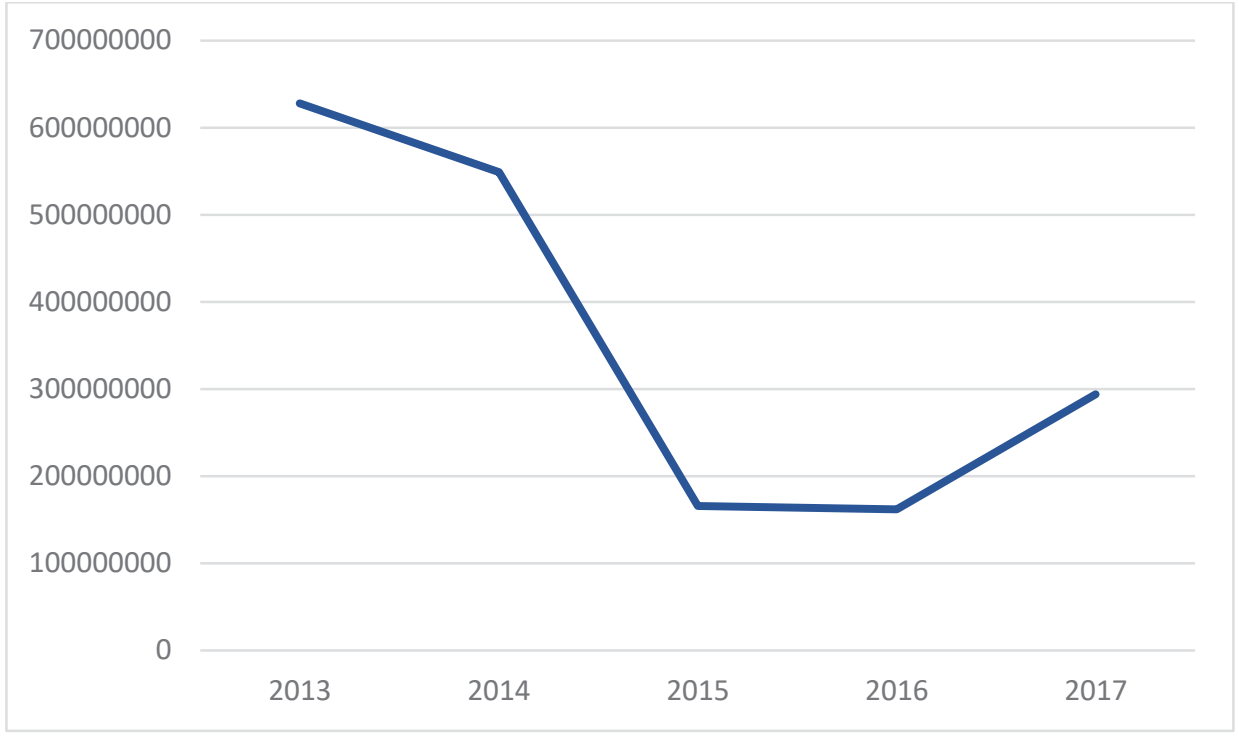

Izvor: Izrada autora prema bazi statističkih podatka WDI (2019)

Indikativno je kako su samo 3 (Ekvador, Alžir i Libija) od 14 zemalja suočene s trgovinskim deficitom. Ostale zemlje bilježe trgovinski suficit, generalno uzlaznog trenda za zadnje godine promatranog razdoblja. Zbrojno gledajući, OPEC obilježava trgovinski suficit s volatilnim trendom.

Najveće vrijednosti pokazatelja trgovinske ravnoteže su zabilježene u primjeru Saudijske Arabije. Saudijska Arabija jedna je od najvećih proizvođača/izvoznika nafte i naftnih proizvoda, a paralelno uvozi automobile, telekomunikacijsku i medicinsku opremu. Uvoznica i izvoznica je zlata i nakita od zlata. Saudijska Arabija također predstavlja ekonomski diversificirano i dinamično tržište. Najveća trgovinska neravnoteža tj. deficit svojstven je za Alžir i Ekvador. Alžir karakterizira relativno slabi monetarni sustav popraćen političkim konfliktima i visokom stopom nezaposlenosti. Izvozi naftu, minerale i elektronske uređaje dok uvozi automobile, brašno i lijekove. Ekvador predstavlja gospodarski siromašnu zemlju, s visokom razinom siromaštva i enormnim javnim dugom. Pored sirove nafte, Ekvador izvozi većinom poljoprivredne proizvode, ribu i kakao. Slijedi prikaz rezultata omjera izvoza i uvoza zemalja OPEC (Tablica 2.) i OPEC-a (Grafikon 3.) 
Tablica 2. Udio izvoza u uvozu (EXIM) za zemlje OPEC-a od 2013. do 2017. godine

\begin{tabular}{|l|r|r|r|r|r|}
\hline Zemlja/Godina & $\mathbf{2 0 1 3}$ & $\mathbf{2 0 1 4}$ & $\mathbf{2 0 1 5}$ & $\mathbf{2 0 1 6}$ & $\mathbf{2 0 1 7}$ \\
\hline Iran & 190 & 173 & 150 & 195 & 205 \\
\hline Irak & 146 & 228 & 119 & 122 & 137 \\
\hline Kuvajt & 390 & 321 & 173 & 150 & 163 \\
\hline Saudijska Arabija & 230 & 203 & 123 & 138 & 174 \\
\hline Venezuela & 196 & 180 & 133 & 189 & 302 \\
\hline Libija & 161 & 112 & 90 & 96 & 210 \\
\hline Ujedinjeni Arapski Emirati & 129 & 127 & 116 & 110 & 114 \\
\hline Alžir & 120 & 103 & 67 & 64 & 76 \\
\hline Nigerija & 203 & 222 & 143 & 93 & 141 \\
\hline Ekvador & 92 & 93 & 86 & 104 & 96 \\
\hline Angola & 253 & 204 & 197 & 261 & 307 \\
\hline Gabon & 281 & 253 & 183 & 203 & 238 \\
\hline Ekvatorijalna Gvineja & 460 & 495 & 400 & 407 & 610 \\
\hline Kongo & 125 & 196 & 189 & 174 & 179 \\
\hline OPEC & 213 & 208 & 155 & 165 & 211 \\
\hline
\end{tabular}

Izvor: Izrada autora prema bazi statističkih podatka WDI (2019)

Grafikon 3. Udio izvoza u uvozu (EXIM) OPEC-a od 2013. do 2017. godine 250

200

150

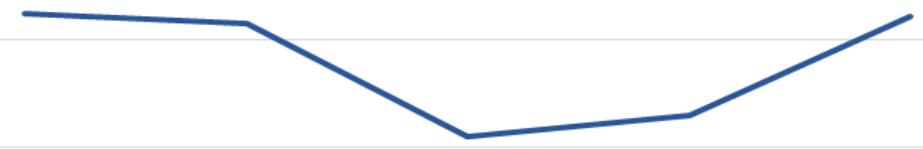

100

50

$\mathrm{O}$

2013

2014

2015

Izvor: Izrada autora prema bazi statističkih podatka WDI (2019) 
Usporedbom rezultata EXIM pokazatelja potvrđen je dominaciju izvoza u odnosu na uvoz zemalja OPEC-a. Vrijednost EXIM pokazatelja prelazi $100 \%$ izuzev Ekvadora i Libije. Rezultati dovode do zaključka kako su promatrane zemlje većinom izvozno orijentirane, ali njihov izvoz je ovisan o proizvodnji i cijeni nafte. Načelno govoreći, grupacija OPEC bilježi također volatilni trend kretanja EXIM pokazatelja. Najveće vrijednosti su vidljive u slučaju Ekvatorijalne Gvineje za koju je i karakteristična pozicija treće zemlje OPEC-a po trgovinskom suficitu. Ovakve tvrdnje imaju uporište budući da je izvoz za otprilike 4,7 puta veći nego uvoz. Suprotno tome, Alžir i Ekvador zabilježile su najmanje vrijednosti omjera izvoza i uvoza u promatranom razdoblju. Kakav je stupanj otvorenosti zemalja OPEC-a, vidljivo je u narednoj Tablici 3. odnosno Grafikonu 4.

Tablica 3. Stupanj trgovinske otvorenosti (TOI) za zemlje OPEC-a od 2013. do 2017. godine

\begin{tabular}{|l|r|r|r|r|r|}
\hline Zemlja/Godina & $\mathbf{2 0 1 3}$ & $\mathbf{2 0 1 4}$ & $\mathbf{2 0 1 5}$ & $\mathbf{2 0 1 6}$ & $\mathbf{2 0 1 7}$ \\
\hline Iran & 50 & 45 & 39 & 43 & 46 \\
\hline Irak & 76 & 78 & 76 & 73 & 74 \\
\hline Kuvajt & 98 & 100 & 99 & 95 & 94 \\
\hline Saudijska Arabija & 83 & 81 & 72 & 62 & 62 \\
\hline Venezuela & 54 & 48 & - & - & - \\
\hline Libija & 135 & 139 & 109 & 110 & 109 \\
\hline Ujedinjeni Arapski Emirati & 166 & 168 & 175 & 177 & 173 \\
\hline Alžir & 64 & 62 & 60 & 56 & 60 \\
\hline Nigerija & 31 & 31 & 21 & 21 & 21 \\
\hline Ekvador & 60 & 58 & 45 & 39 & 42 \\
\hline Angola & 95 & 90 & 70 & 59 & 58 \\
\hline Gabon & 91 & 74 & 74 & 71 & 70 \\
\hline Ekvatorijalna Gvineja & 107 & 104 & 99 & 93 & 94 \\
\hline Kongo & 77 & 79 & 59 & 75 & 75 \\
\hline OPEC & 85 & 83 & 77 & 75 & 75 \\
\hline
\end{tabular}

Izvor: Izrada autora prema bazi statističkih podatka WDI (2019) 
Grafikon 4. Stupanj trgovinske otvorenosti (TOI) za OPEC od 2013. do 2017. godine

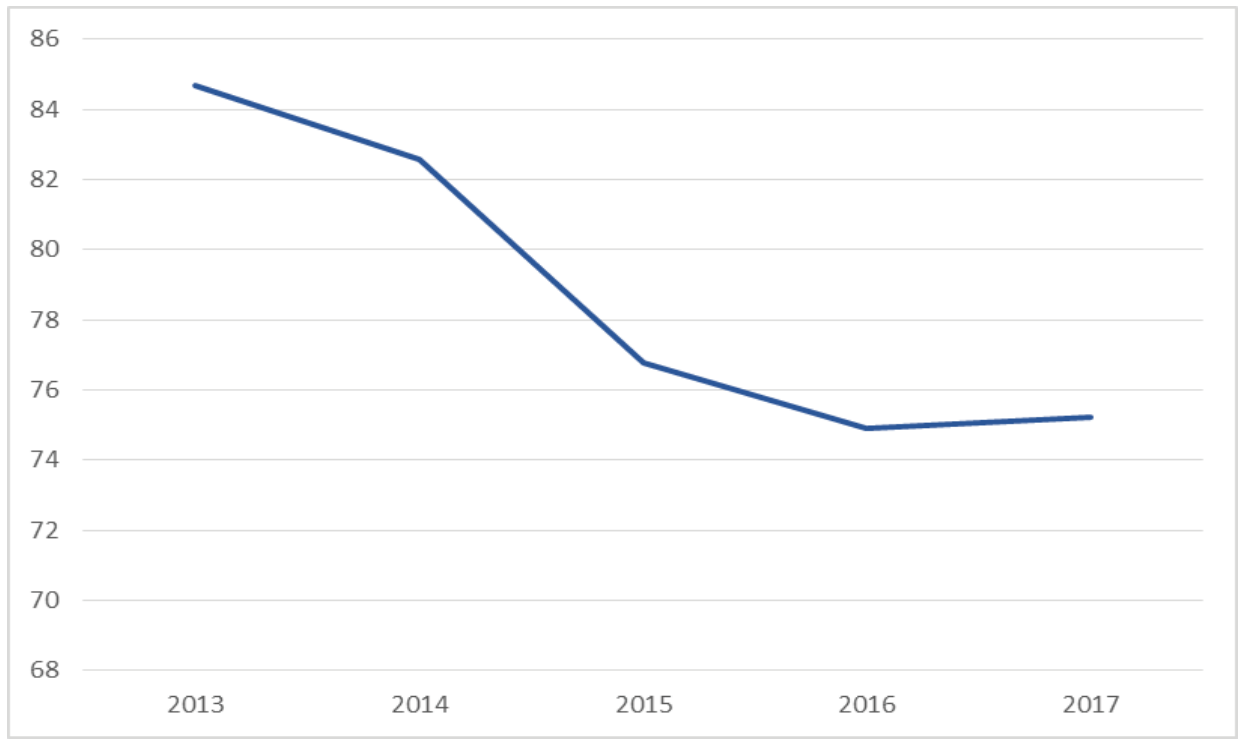

Izvor: Izrada autora prema bazi statističkih podatka WDI (2019)

Najveća razina trgovinske otvorenosti zabilježena je u primjeru Libije i Ujedinjenih Arapskih Emirata, dok je Ekvatorijalna Gvineja treća po redu. Libija značajno ovisi o energetskom sektoru koji čini 95\% njenog izvoza, 80\% BDP-a i 99\% javnih prihoda. Ulaskom u WTO i liberalizacijom trgovine Libija se otvorila inozemnim ulaganjima i postala je otvorenijom zemljom. Ujedinjeni Arapski Emirati predstavljaju trgovinski najotvoreniju zemlju članicu OPEC-a. UAE karakterizira reeksport, intenzivna trgovina kao i visoki stupanj ekonomskog razvoja. Najniža razina trgovinske otvorenosti zabilježena je u Nigeriji, Iranu, Ekvadoru i Venezueli. Politička nestabilnost, relativno visoka stopa inflacije kao i ograničeni izvoz predstavljaju ograničenja za Nigeriju.

Iran je suočen s sankcijama SAD-a što uvelike ugrožava trgovinsku otvorenost Irana, Ekvador se susreće s gospodarskim izazovima, dok je Venezuela u ozbiljnoj gospodarskoj i političkoj krizi. Načelno govoreći, evidentan je silazni trend stupnja trgovinske otvorenosti zemalja OECD-a od 2013. do 2017. godine.

Sljedeća Tablica 4. i Grafikon 5. prikazuju udio izvoza u BDP-u zemalja OPECa u razdoblju od 2013. do 2017. godine. 
Tablica 4. Udio izvoza u BDP-u (EGDP) zemalja OPEC-a od 2013. do 2017. godine

\begin{tabular}{|l|r|r|r|r|r|}
\hline Zemlja/Godina & $\mathbf{2 0 1 3}$ & $\mathbf{2 0 1 4}$ & $\mathbf{2 0 1 5}$ & $\mathbf{2 0 1 6}$ & $\mathbf{2 0 1 7}$ \\
\hline Iran & 26,88 & 23,14 & 19,74 & 22,4 & 23,79 \\
\hline Irak & 39,68 & 41,34 & 34,92 & 32,52 & 37,63 \\
\hline Kuvajt & 70,86 & 68,51 & 53,77 & 48,23 & 50,14 \\
\hline Saudijska Arabija & 51,92 & 46,88 & 33,32 & 31,14 & 34,84 \\
\hline Venezuela & 24,77 & 16,69 & - & - & - \\
\hline Libija & 70,43 & 47,01 & 39,97 & 26,14 & 37,94 \\
\hline Ujedinjeni Arapski Emirati & 100,63 & 99,11 & 100,87 & 101 & 100,38 \\
\hline Alžir & 33,21 & 30,22 & 23,17 & 20,86 & 22,64 \\
\hline Nigerija & 18,05 & 18,44 & 10,66 & 9,22 & 13,17 \\
\hline Ekvador & 28,64 & 28,05 & 21,26 & 19,5 & 20,83 \\
\hline Angola & 50,75 & 44,69 & 29,76 & 28,12 & 29 \\
\hline Gabon & 57,36 & 44,52 & 46,03 & 44,03 & 50,46 \\
\hline Ekvatorijalna Gvineja & 67,65 & 65,96 & 56,67 & 51,29 & 57,42 \\
\hline Kongo & 36,45 & 36,83 & 27,73 & 27,22 & 35,6 \\
\hline OPEC & 48,38 & 43,67 & 38,3 & 35,51 & 39,53 \\
\hline
\end{tabular}

Izvor: Izrada autora prema bazi statističkih podatka WDI (2019)

Grafikon 5. Udio izvoza u BDP-u (EGDP) zemalja OPEC-a od 2013. do 2017. godine 60

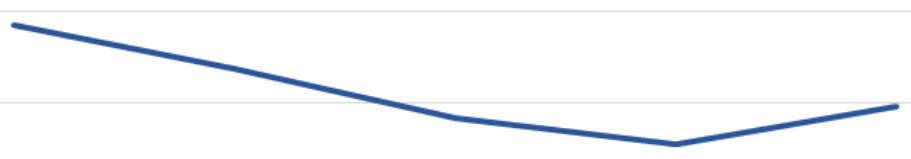

0

Izvor: Izrada autora prema bazi statističkih podatka WDI (2019) 
Udio izvoza u BDP-u zemalja OPEC-a bilježi silazni trend izuzev 2016. godine. Načelno govoreći, udio izvoza zemalja OPEC-a kreće se između 40\% i 50\%. Najveći udio izvoza u BDP-u zabilježili su Ujedinjeni Arapski Emirati s prosječnim udjelom od $100 \%$. Najniži udio izvoza u BDP-u zemalja OPEC-a je zastupljen u primjeru Nigerije, Venezuele i Irana. Ove zemlje karakterizira politička nestabilnost, gospodarska stagnacija tj. otežan gospodarski razvoj koji definitivno impliciraju na njihovu oslabljenu izvoznu propulzivnost.

OPEC ima važnu ulogu u formiranju količine proizvodnje tj. cijene nafte. Narušena političko-sigurnosna situacija na području zemalja OPEC-a, kao i usporavanje gospodarskog rasta najvećih izvoznika na svijetu (npr. Kina) te klimatski čimbenici imaju značajan utjecaj na cijenu nafte. Posljedično tome, značaj cijene nafte potvrđuje istraživanje Yoshinoa i Alekhina (2016) koji ističu kako cijena nafte ima direktni utjecaj na zemlje izvoznice nafte koje itekako ovise o njihovim izvoznim prihodima.

\section{ZAKLJUČNA RAZMATRANJA}

Istraživanje prati otvorenost vanjskotrgovinske razmjene 14 zemalja članica međunarodne organizacije OPEC. Korišteni su pokazatelji poput intraindustrijske razmjene (IITR), udio izvoza u uvozu (EXIM), pokazatelj vanjskotrgovinske ravnoteže (TBAL), udio izvoza u BDP-u (EGDP), i to za razdoblje od 2013. do 2017. godine. Analizom rezultata pokazatelja može se potvrditi temeljna hipoteza rada koja pretpostavlja visoku trgovinsku otvorenost i izvoznu orijentiranost većine zemalja članica OPEC-a. Zaključak je kako prosjek OPEC grupacije bilježi pretežito silazni trend u trgovini osim 2016. godine. Razlog tome je snažno smanjenje cijene nafte koji predstavlja glavni izvozni proizvod grupacije OPEC.

Sredinom 2014. godine, cijena nafte počela je padati zbog značajnog povećanja proizvodnje nafte u SAD-u i pada potražnje u zemljama u razvoju. Cijena - uzrokovana višestrukim internim i eksternim čimbenicima - potaknulo je oštar spiralni pad cijene nafte koja s tendencijom pada do veljače 2016. godine. Do 3. veljače 2016. cijena nafte je bila ispod 30 dolara što predstavlja pad od gotovo 75 posto od sredine 2014. godine. Razlog leži u proizvodnji konkurentskih proizvođača koja je iznosila 1 do 2 milijuna barela sirove nafte dnevno, dok je paralelno kinesko gospodarstvo ostvarilo najniži rast.

Štoviše, zbog prevelike ponude i nedostatka sporazuma između zemalja proizvođača OPEC-a (posebice Saudijske Arabije, koja je obarala svjetske rekorde po proizvodnji nafte), i zbog nedostatka koordiniranih napora između zemalja OPEC-a i zemalja koje nisu članice OPEC-a (Rusija je odbila smanjiti proizvodnju) cijena nafte naglo je pala u 2015., i nastavila se smanjivati u 2016. godini uzrokujući pad cijena sirove 
nafte i to na najnižu razinu u razdoblju od 10 godina. Prosječna cijena nafte u siječnju 2016. bila je znatno ispod \$ 35 dolara. Cijena nafte se nije oporavila sve do travnja 2016. godine, kada je nafta nadmašila razinu od 45 dolara.

Razvijene zemlje poput Saudijske Arabije, Ujedinjenih Arapskih Emirata predstavljaju vodeće zemlje u trgovinskoj otvorenosti i izvoznoj propulzivnosti. Te zemlje bile su suočene s ograničenjima posebice tijekom oštrog pada cijena nafte. Paralelno s time, iako oslabljene, pokazale su rezistentnost na negativne šokove cijene nafte. S druge strane postoji grupa zemalja OPEC-a koje se svakodnevno suočavaju s političkom nestabilnošću i usporenim gospodarskim razvojem odnosno gospodarskim padom. U tu domenu ulaze zemlje poput Ekvadora, Alžira, Libije, ali i Venezuela i Iran koje nisu pokazale zavidne rezultate u trgovinskoj otvorenosti i izvoznoj propulzivnosti. Glavni preduvjet jačanja izvozne aktivnosti zemalja OPEC-a je institucionalna tj. politička stabilnost, zajedničke odluke zemalja članica OPEC-a, ali i vanjski čimbenici poput gospodarskog razvoja najvećih zemalja i zemalja izvoznica svijeta.

\section{LITERATURA:}

1. Almoguera, P.A., Douglas, C.C., Herrera, A.M., (2011) Testing for the cartel in OPEC: noncooperative collusion or just noncooperative? Oxf. Rev. Econ. Policy 27 (1), 144-168. doi: https://doi.org/10.1093/oxrep/grr007

2. Bezić H.; Galović T., (2014) The International Trade of European Chemical Industry, Advances in Business-Related Scientific Research Conference $A B S R C$ 2014, GEA COLLEGE - Faculty of Entrepreneurship, dostupno na: http://www.absrc.org/publications/past-conference-proceedings/proceedingsrome-2014/

3. Boug, P., Cappelen, Å., Swensen, A.R., (2016) Modelling OPEC Behavior. Theory and Evidence. Discussion Papers 843. Statistics Norway, dostupno na: http://hdl.handle.net/10419/192825

4. CFR (2019), https://www.cfr.org/backgrounder/opec-changing-world

5. Griffin, J.M. (1985) OPEC behavior: a test of alternative hypothesis. Am. Econ. Rev. 75(5), 954-962., dostupno na: www.jstor.org/stable/1818638

6. Galović, T.; Mišević P.; Popović, (2017). L., The Export Competitiveness of EU28 Countries, TRADE PERSPECTIVES 2017 Specialization and Customer Centered Retailing, Ekonomski fakultet Zagreb i Hrvatska gospodarska komora, 2017. str. 15-31, dostupno na: http://www.efzg.unizg.hr/UserDocsImages/TRG/trade\%20perspectives2017/P ROCEEDINGS\%202017.pdf 
7. Galović T.; Bezić H.; Primorac D. (2018) The Export Competitiveness of NAFTA Countries, Economic and Social Development, Split, 2018. str. 493502. dostupno na: https://www.esdconference.com/upload/book_of_proceedings/Book_of_Proceedings_esdSplit2 018 Online.pdf

8. Kandžija V., Bezić H., Galović, T., (2014) The International Trade of EU Food, Beverages and Tobacco Sector, Economic System of European Union and Accession of Bosnia \& Herzegovina, Vitez University of Travnik, University of Rijeka - Faculty of Economics - Jean Monnet Chair, Institute CEDIMES Rijeka, University of Antwerp - Jean Monnet Centre of Excellence, University of Ljubljana - Faculty of Economics - Chair Jean Monnet, University of Belgrade - Faculty of Organizational Sciences, University of Zagreb - Faculty of Economics and Business, University of Osijek - Faculty of Economics Institute CEDIMES Paris, str. 289-309., dostupno na: https://unvi.edu.ba/Files/zbornici/Zbornik\%20radova\%20sa $\% 20$ trece $\% 20$ medj unarodne $\% 20 \mathrm{konferencije} \% 20$ \%20Ekonomski\%20sistem\%20EU\%20i\%20pristupanje\%20Bosne $\% 20 \mathrm{i} \% 20 \mathrm{He}$ rcegovine.pdf

9. OPEC (2019), https://www.opec.org/opec web/en/about us/24.htm

10. Smith, J.L., 2005. Inscrutable OPEC? Behavioral Tests of the Cartel Hypothesis. Energy J. 26 (1), 51-82., doi: https://doi.org/10.5547/issn0195-6574-ej-vol26$\underline{\text { no1-3 }}$

11. Spilimbergo, A., 2001. Testing the hypothesis of collusive behavior among OPEC members. Energy Econ. 23, 339-353., doi: https://doi.org/10.2139/ssrn.223809

12. Svjetska banka (2018), dostupno na:

http://data.worldbank.org/indicator/NY.GDP.MKTP.CD?end=2015\&locations $=$ EU\&start $=2011$

13. Yoshino, N. and V. Alekhina. 2016. Impact of oil price fluctuations on an energy exporting economy: evidence from Russia, Journal of Administrative and Business Studies 2(4): 156-166., doi: https://doi.org/10.20474/jabs-2.4.2

14. WDI - World Development Indicators (2019) dostupno na: https://datacatalog.worldbank.org/dataset/world-development-indicators 


\section{INTERNATIONAL TRADE OF OPEC MEMBERS}

\section{Petar Mišević}

\section{Summary}

Organization of the Petroleum Exporting Countries (OPEC) as an international organization with its oil price correction instruments has a significant impact on economic systems and international trade around the world. The paper analyses the international trade of OPEC Member states for the period 2013 - 2017. The analysis used indicators of trade balance, intra-industry trade, export share in imports, trade openness and share of exports in GDP. The research results will show how much OPEC members are opened in trade and export-oriented. Based on the results of the research, the recommendations and suggestions of the research are presented.

Key words: indicators of foreign trade, OPEC, export, import. 